\title{
Ñaupax Manpuni [Olhar o Passando Mirando o Futuro]: O Protagonismo Indígena nas Lutas Populares da Bolívia (da Comunidade ao Estado)
}

\author{
Mariana Bruce ${ }^{1}$
}

Resumo: A eleição de Evo Morales em 2005 abriu um novo horizonte de sentido para refletir sobre a questão indígena no continente, pois, pela primeira vez, foram rompidas as barreiras de um Estado colonial, racista e patriarcal em favor do movimento indígena auto representado que, por conseguinte, redefiniu o Pacto Social vigente tornando a Bolívia um Estado Plurinacional e Comunitário. A proposta deste artigo é analisar, a partir da teoria decolonial - mais especificamente atrelada à perspectiva do "giro decolonial" --, de que maneira se articulam um tempo de longa duração, milenar, que remonta à estruturação da comunidade indígena, e o tempo curto, conjuntural, no qual houve um processo crescente de etnização da política e de protagonismo indígena na definição dos rumos de todo um país. Entre mudanças e permanências, realizo uma reflexão sobre o processo que levou à ascensão do Governo Evo Morales e alguns de seus aspectos subsequentes.

Palavras-chave: Bolívia, Estado, movimentos sociais

\section{Naupax Manpuni [Watching the Past Aiming at the Furture]: Indigenous Protagonism in the Popular Struggles of Bolivia (from Community to State)}

\begin{abstract}
The election of Evo Morales in 2005 opened a new horizon of meaning to reflect on the indigenous issue in the continent, because, for the first time, the barriers of a colonial, racist and patriarchal state were broken in favor of the self-represented indigenous movement, thus redefining the Social Pact in force, making Bolivia a Plurinational and Community State. The purpose of this article is to analyze, based on the decolonial theory more specifically linked to the perspective of the "decolonial giro" -, how a long-lasting, millennial time that dates back to the structuring of the indigenous community is articulated, and the short-term, conjunctural period, in which there was a growing process of ethnicization of politics and indigenous protagonism in defining the directions of an entire country. Between changes and permanences, I reflect on the process that led to the rise of the Evo Morales Government and some of its subsequent contradictions.
\end{abstract}

\footnotetext{
1 Doutora em História Social pela Universidade Federal Fluminense (PPGH/UFF), com a tese "Estado Plurinacional e Comunitário na Bolívia: As Lutas Populares e o Bem Viver a partir de El Alto" (2019) e pesquisa financiada pelo CNPq. Correio eletrônico: brucemariana@gmail.com.
} 
Keywords: Bolivia, State, social movements

Artigo recebido em: 20/01/2020

Artigo aprovado para publicação em: 07/05/2020

\section{Introdução}

A eleição de Evo Morales, em 2005, abriu um novo horizonte de sentido para refletir sobre a questão indígena no continente, pois, pela primeira vez, foram rompidas as barreiras de um Estado colonial, racista e patriarcal em favor do movimento indígena autorepresentado que, por conseguinte, redefiniu o Pacto Social vigente tornando a Bolívia um Estado Plurinacional e Comunitário. A proposta deste artigo é refletir sobre os elementos que contribuíram para ascensão de Morales à Presidência, bem como algumas das transformações e contradições decorrentes, partindo de uma perspectiva decolonial que confere protagonismo ao sujeito indígena, invisibilizado pela história oficial.

A perspectiva decolonial aqui referenciada inspira-se no "giro decolonial" tal como definido por Nelson Maldonado-Torres $(2007,2008)$, que chama atenção para o movimento de resistência existente na América Latina, tanto teórico quanto prático, tanto político quanto epistemológico à modernidade colonial estabelecida mundialmente a partir do século XVI. O giro busca conferir cientificidade às falas, saberes e práticas de sujeitos até hoje silenciados destacando fontes, referências bibliográficas e metodologias que remetem a abordagens sobre a história e os fenômenos sociais que rompem com o eurocentrismo imperante.

Por eurocentrismo, entende-se uma perspectiva de conhecimento que, entre outras coisas, institui a "existência de um sujeito epistêmico que não tem sexualidade, gênero, etnia, raça, classe, espiritualidade, língua, nem localização epistêmica em nenhuma relação de poder, e produz a verdade desde um monólogo interior consigo mesmo, sem relação com ninguém fora de si”. E deste modo, engendra-se "uma filosofia surda, sem rosto e sem força 
de gravidade". Uma perspectiva que "é assumida pelas ciências humanas a partir do século XIX como a epistemologia da neutralidade axiológica e da objetividade empírica do sujeito que produz conhecimento científico” (GROFOGUEL, 2007, p. 64-65).

Foi na contramão desse entendimento e intercedendo em favor dos povos colonizados, que a partir dos anos 1950 e 1960 observa-se, primeiramente com a literatura pós colonial e, na sequência, com os subaltern studies indiano e os estudos culturais das décadas seguintes, um esforço significativo em modificar a base epistemológica das ciências sociais.

Para os fins deste artigo, gostaria de chamar atenção principalmente para o fato de como Aimé Cesaire (1950) e Frantz Fanon (1952, 1961), originários da Martinica, Albert Memmi (1965), da Tunísia, Edward Said (1978), da Palestina, ainda que tenham construído suas carreiras intelectuais nos centros universitários europeus, partiram desses lugares periféricos para lançar novas hipóteses sobre o colonialismo com o objetivo de compreendêlo, bem como suas consequências para a humanidade, a partir da perspectiva do colonizado. $\mathrm{Na}$ Índia, nos anos 1970 e 1980, um forte grupo de intelectuais, dentre os quais Ranajit Guha (1988), Gayatri Spivak (1988) e Dipesh Chakrabarty (2000), também questionaram, por meio do chamado subaltern studies, os princípios da historiografia colonial, nacionalista e eurocêntrica, do ortodoxismo da teoria marxista e, inclusive, do pós-modernismo desconstrutivista, para reivindicar traduções ${ }^{2}$ necessárias dos parâmetros da modernidade para o entendimento da realidade indiana. Por fim, vale destacar ainda as contribuições do campo dos Estudos Culturais ou Multiculturais, que tem na obra de Stuart Hall (2011),

\footnotetext{
${ }^{2}$ A noção de tradução foi proposta por Dipesh Chakrabarty, autor indiano, teórico do Subaltern Studies em seu livro Provincializing Europe (2000). O autor se propõe a analisar a construção da Modernidade na Índia e, para tanto, faz um importante exercício no sentido de reconhecer o legado das práticas e valores europeus modernos difundidos durante os processos de colonização, mas, ao mesmo tempo, destaca também as diferentes apropriações, ressignificações ou traduções feitas pelo colonizado (CHAKRABARTY, 2000). Para Chakrabarty, provincializar a Europa significa compreender a construção da modernidade na Índia a partir de um referencial europeu, mas indo além dele, reconhecendo o diálogo com as idiossincrasias locais.
} 
intelectual jamaicano que fez sua carreira acadêmica na Inglaterra, uma de suas principais referências.

O giro decolonial latino-americano propriamente dito ganha consistência a partir dos anos 1990 com o estabelecimento de um grupo de estudos que avança na reflexão sobre a Modernidade/Colonialidade. São intelectuais que bebem de todas as fontes anteriormente citadas, pois estão comprometidos em dar maior visibilidade ao outro da relação com a Europa, mas que dão o salto de deslocar o lócus colonial da Europa ou mesmo da Índia para as especificidades do nosso continente, sem perder de vista a importância das discussões de categorias de ordem política, de classe, gênero e outros deixado de lado em muitos estudos de recorte mais culturalista.

Assim, Anibal Quijano, Walter Mignolo, Enrique Dussel, Edgardo Lander, Immanuel Wallerstein são alguns dos autores que constituem esse grupo de intelectuais que formulam uma teoria original sobre a constituição da modernidade, a partir de sua face colonial estabelecida nas Américas. No âmbito do que ficou estabelecido como "colonialidade do poder, do saber e do ser" (LANDER, 2005), os autores apontam para vários aspectos da Modernidade-Colonial que se perpetuam no continente mesmo após o fim do colonialismo. Um deles é o "colonialismo interno" recentemente redefinido por Pablo Gonzalez Casanova (2007), que chama atenção para a forma como as oligarquias estabeleceram padrões de dominação no âmbito político, econômico e cultural que remetem aos cânones eurocêntricos com duras consequências para a história dos povos do continente, em particular os indígenas, uma vez que a questão racial segue presente. Em relação a esse último aspecto, trata-se de destacar que uma das consequências do estabelecimento da Modernidade-Colonial nas Américas é o entendimento de que a classificação social deriva de uma definição do outro como diferente e subalterno em relação à superioridade e pureza de sangue da raça branca. Desse modo, a diferenciação racial entre brancos, negros e indígenas constitui-se como o princípio organizador que estrutura as múltiplas hierarquias nesse sistema-mundo e que traz 
como uma de suas consequências mais drásticas uma práxis de violência sem precedentes tanto física (genocídio) quanto epistêmica (epistemicídio).

Devolver o protagonismo ao sujeito indígena e refletir sobre a história do continente a partir desse lugar é, portanto, um ato de re-existência ${ }^{3}$ ao mundo moderno-colonial. Vale notar que se o grupo de estudos da Modernidade/Colonialidade é relativamente recente no campo das Ciências Sociais, os esforços em pensar a realidade do continente a partir desse lugar de fala, considerando a especificidade latino-americana e sem perder de vista um diálogo com o legado do mundo moderno-colonial, já existem desde longa data. Silvia Rivera Cusicanqui (2015) debruça-se, por exemplo, no que ela chama de Sociologia de la Imagen com intuito de reinterpretar a história da Bolívia a partir das imagens produzidas por pintores como Guamán Poma de Ayala (1534-1615), pois esse tipo de fonte, de acordo com a autora, oferece a possibilidade de alcançar dimensões que não seria possível caso nos mantivéssemos restritos à narrativa escrita. A despeito de sua conversão à fé católica e de ter se inserido na lógica social ou no habitus criollo, personagens como Guamán Poma trazem muito de um horizonte indígena silenciado, negado e omitido.

Outro exemplo mais contemporâneo de intelectual que reflete sobre o continente a partir desse olhar original, e que tomamos como referência para os fins da análise, é José Carlos Mariátegui. No que diz respeito ao indígena, desde os anos 1920, o intelectual peruano já dizia que “o problema do índio também era um problema da terra”. Desse modo, Mariátegui unia classe e identidade, indo além dos aspectos da etnicidade ou da reparação moral como então predominavam as abordagens que se voltavam para essa temática. Mariátegui também sinalizava como "o poder da comunidade era de extrema relevância para se refletir sobre o passado e o futuro dos povos indígenas no continente" (MARIÁTEGUI,

\footnotetext{
3 O uso da expressão "re-exsitência" não é ingênuo, pois tem por objetivo enfatizar como a resistência à modernidade colonial também significa um processo permanente de redefinição das próprias condições de existência de cada povo sem, contudo, abrir mão de sua condição de sujeito autônomo diante desses processos (Cf PORTO-GONÇALVES, 2002).
} 
2008, p. 58). Por isso, o reconhecimento do indígena como um sujeito histórico era de fundamental importância para se avançar em uma compreensão mais refinada sobre essa história e as estratégias de superação da dominação colonial-imperialista que perdurava mesmo após a independência.

Muitas reflexões ao longo dos anos apontaram no sentido de entendimento desse lugar protagônico dos povos indígenas e/ou da necessidade de se interpretar a realidade do continente a partir de uma lente específica ${ }^{4}$. Porém, o giro decolonial do final do século XX e, sobretudo na primeira década do século XXI, acaba por definir um campo científico de produção epistêmica com vários desdobramentos sobre o entendimento que se faz sobre o passado, o futuro e o papel dos povos indígenas na condução da história.

Desse modo, na medida em que a eleição de Morales na Bolívia atrai maior visibilidade ao fenômeno indígena no continente e inspirada pelas provocações ensejadas pelos autores anteriormente citados, busco neste artigo recuperar uma história que não se esgota na figura do próprio Presidente, mas que remete a um longo processo de reestruturação das lutas populares e indígenas nesse país. Assim, volto o olhar para esse passado da Bolívia compreendendo a importância de resgatar o protagonismo indígena como eixo estratégico para o entendimento da história que se segue. Tratam-se das re-existências a que me referi anteriormente, que seguem sustentando outras formas de viver que não foram derrotadas nos mais de 500 anos de colonialismo e que são marcadamente influenciadas pela força e potência da comunidade indígena.

Portanto, para alcançar essa história silenciada, marginalizada, debrucei-me sobre alguns autores considerados "indigenistas”, como René Zavaleta Mercado, Silvia Rivera Cusicanqui e Álvaro García Linera, que se propõem a reescrever a história a partir das classes

\footnotetext{
${ }^{4}$ Poderia citar a teoria da dependência, a pedagogia do oprimido, a teologia da libertação, a ecologia política desde os territórios (desde abajo), a teoria do colonialismo interno, a teoria da autopoiesis, a teoria da investigação-ação participativa, como contribuições originais e de fundamental importância que evidenciam a densidade teórico-prática existente no continente (Cf. PORTO-GONÇALVES in DILGER, LANG E NETO, 2016).
} 
populares e indígenas. Se por um lado tais abordagens suprem algumas lacunas deixadas pelas abordagens hegemônicas oficiais, de matrizes eurocêntricas, por outro criam novos desafios que ainda precisam ser superados, como o fato de muitas vezes esbarrarem em certa romantização dos oprimidos e explorados, ou em uma apologia do sujeito autóctone/original, ou mesmo em um desconstrutivismo paralisante que resulta na saída do próprio campo científico que está em disputa, tal como sugere Ballestrin (2013, p. 70). Outrossim, como o diálogo com esses autores no Brasil ainda é deveras rarefeito, no presente artigo, vou me ater aos aspectos construtivos que tais abordagens podem nos oferecer no sentido de nos aproximarmos de outras interpretações possíveis desse passado da Bolívia - que, como qualquer outra abordagem sobre a história, estão fortemente atreladas ao olhar que é lançado para o futuro - e reservo para um outro momento mais oportuno um aprofundamento das críticas e contradições ensejados por esse caminho.

Começo, então, por René Zavaleta Mercado (1977), que tem um entendimento das elites na Bolívia como uma "casta encomendera" que se creem donas do país devido a uma herança colonial e que, ao mesmo tempo, o desprezam. Tais elites, oriundas principalmente do setor mineiro, latifundiário e de grandes comerciantes, constroem uma relação de subserviência histórica às organizações internacionais, no âmbito de um modelo econômico que reafirma a dependência em relação às potências imperialistas e subimperialistas dentro de um viés extrativista de alto potencial destrutivo. Além disso, estabelecem uma relação com o povo fundamentada no racismo estrutural que não reconhece o indígena como sujeito, mas sim como obstáculo para a viabilização de seu projeto de nação.

Em relação a esse último aspecto, a dicotomia operada por essas elites em torno da qual se opõe a "civilização" e a "barbárie" resulta em esforços constantes de silenciar, negar ou até mesmo extinguir a presença indígena do país, tal como previsto na lógica modernocolonial acima apontada que não é interrompida com a independência, mas reproduzida internamente mesmo sob um contexto republicano. Desse modo, a República criolla na 
Bolívia se apresenta racista em um nível extremo, pois não reconhece sequer a existência dos povos indígenas e estabelece uma relação com esses povos marcada por profunda violência como veremos a seguir. Por essa razão, "a rebelião passa a se constituir também como a linguagem fundamental através da qual o indígena se impõe diante de uma sociedade excludente e racista que não admite sua existência" (RIVERA CUSICANQUI, 2010, p. 74-75). Para Álvaro García Linera, a rebelião é o lócus do qual é possível extrair uma compreensão profunda dos sentidos e significados do movimento indígena, haja vista sua natureza predominantemente ágrafa. Mais além, o autor afirma que a "comunidade e suas rebeliões" são o "fundamento esclarecedor do chamado indígena” (LINERA, 2010, p. 162). Na rebelião, são "reabilitados os parâmetros comunitários da vida cotidiana e que servem como ponto de partida, inclusive, para a defesa de uma nova ordem socioeconômica porque são colocados em prática mecanismos de democracia direta e representativa que desafia o Estado criollo" (IDEM, p. 165-166).

Às tentativas das classes populares e indígenas de se apresentarem como sujeitos capazes de formular suas próprias demandas e anseios, a "casta encomendera" respondeu com repressão e massacres. No entanto, são essas classes populares e indígenas os sujeitos que melhor têm apontado os limites reais da democracia no país, pautando temas centrais e estratégicos, não apenas do ponto de vista da realidade concreta boliviana, mas de pertinência global, tais como: a questão da soberania, da autodeterminação dos povos, da propriedade sobre os recursos naturais, sobre os direitos da natureza, direitos trabalhistas, direitos sobre a propriedade coletiva, direitos políticos, sociais e culturais de forma geral, a formulação sobre o Bem Viver ${ }^{5}$, entre outros. Contudo, ainda que relevantes todos esses temas, para os fins deste artigo vou debruçar-me mais sobre os aspectos de reescrita da história, a partir da

\footnotetext{
${ }^{5}$ Para uma discussão mais aprofundada sobre o conceito do Bem Viver, confira meu artigo O Bem Viver e a Reforma do Estado na Bolívia (2019). Segundo Alberto Acosta (O Bem Viver, 2016), no cerne do Bem Viver está implícito um grande passo revolucionário que nos leva a caminhar de visões antropocêntricas a visões sociobiocêntricas, assumindo as consequências políticas, econômicas, culturais e sociais dessa transição.
} 
Mirada Decolonial, com intuito de contextualizar em um sentido mais amplo a ascensão de Morales à Presidência da Bolívia e algumas das transformações decorrentes.

\section{O Tempo Longo: A Re-existência da Comunidade Indígena a partir da Mirada Decolonial}

A história da Bolívia não começa com a chegada dos espanhóis e o processo de colonização. Ao contrário, há uma história milenar que remete ao processo de conformação da comunidade indígena a partir de diferentes tradições étnico-culturais. Pouco antes da chegada dos espanhóis, o Kollasuyu do Império Inca (isto é, o território correspondente à província do sul que englobava o Lago Titicaca indo da Bolívia até o Chile setentrional) constituía-se como um de seus quadrantes mais rebeldes ${ }^{6}$ e, como os demais, estruturavamse tendo como base uma federação de ayllus, "comunidades aldeãs que reúnem várias famílias vinculadas por algum grau de parentesco, onde são estabelecidos laços de reciprocidade e são conformadas suas identidades"(Cf. ESTERMAN, 2005).

Como o Império Inca, o Estado colonial espanhol também se apoiou nas estruturas dos ayllus para governar sobre os povos originários, de maneira que, da época pré-incaica até os dias atuais, apesar das muitas transformações pelas quais passou, o ayllu, sobretudo no campo, permanece como unidade básica de organização socioeconômica e cultural. Contudo, o fato de se apoiarem na estrutura dos ayllus para governar não significa que os espanhóis reconheciam a condição milenar de existência dos povos originários. Ao longo da história, a despeito da composição multiétnica existente, suas línguas, costumes, valores e culturas foram ignorados e invisibilizados.

\footnotetext{
${ }^{6}$ O Império Inca também pode ser denominado como Tawantinsuyu, o Império dos Quatro Quadrantes do Sol. Um império composto por mais de 10 milhões de habitantes e que se estendia de Cali, na Colômbia, até Valdívia, no sul do Chile, e que abrangia desde o Oceano Pacífico à selva amazônica.
} 
Segundo René Zavaleta Mercado (1977), o viés etnocêntrico assumido pelo Estado Colonial contribuiu na constituição de uma "sociedad abigarrada". Trata-se de uma concepção que pressupõe que entre os povos originários ocorreu um processo de dialética sem síntese entre as distintas culturas, como se tais identidades se relacionassem por meio de uma justaposição na qual se considera o fato de que os povos originários tiveram que assimilar uma identidade mestiça para serem inseridos perante o Estado e os direitos fundamentais, porém, sem que isso significasse substituir suas identidades tradicionais. Em outras palavras, é como se a tensão ou as contradições entre diferentes complexos culturais (com assimétricas relações de poder) coexistissem sem necessariamente criar uma terceira via. Essa noção ajuda a compreender a condição de existência dos indígenas sob certas circunstâncias de dominação, nas quais foram criadas brechas para a reprodução de suas estruturas milenares, sem, contudo, haver um reconhecimento do Estado de sua existência de fato. Vale notar que "o fato de não haver a síntese dessas diferenças, não significa dizer que não haja intercâmbios, comunicação e articulações possíveis. Essas pontes nem sempre são verbalizadas, mas existem” (Cf. CUSICANQUI \& SANTOS, 2013).

Desse modo, tais estruturas sociais correspondentes às comunidades ou às zonas autônomas de existência passaram a coexistir com a realidade moderna-ocidental. Naquelas, a despeito de toda a missão civilizatória do homem branco, foram mantidas a reprodução de valores e racionalidades próprios, cuja comunicação se dá a partir de diferentes formas sobretudo pela força das tradições orais e dos rituais. São nessas realidades e intercâmbios que acabam sendo produzidas alternativas antissistêmicas ${ }^{7}$ de forma permanente.

\footnotetext{
${ }^{7}$ Ao tratar da perspectiva antissistêmica, tenho como referência a sugestão de Mignolo (2010, p. 17) da "pluriversalidade como horizonte universal", isto é, ao passo em que se insiste em seguir costurando novos horizontes utópicos e radicais para a libertação humana, não se propõe a substituição desse mundo modernocolonial por um outro sistema de pretensão universal, mas, sim, busca-se enfatizar essa pluralidade de possibilidades construídas a partir das múltiplas resistências periféricas.
} 
Segundo relatório da CEPAL (2015), a Bolívia é um dos países com maior proporção de população indígena das Américas (62,2\%), seguido por Guatemala (41\%) e México $(15,1 \%)$ de um total de 45 milhões de indígenas existentes no continente. Embora seja apresentada muitas vezes como uma minoria exótica remanescente de um passado imemorial, a existência coetânea dos povos originários é uma evidência empírica. E apesar do desejo das elites de reconhecer o mundo índio como uma "minoria inofensiva y ornamental" encerrada em "museos y reservas ecologicas" sem "capacidade de incidir sobre o delineamento das políticas públicas" (RIVERA CUSICANQUI, 2010, p. 66), o fato é que os indígenas se recusam a assumir esse lugar, e impulsionados pela potência da comunidade intervêm politicamente sobre a realidade, apontando as contradições estruturais da Modernidade Colonial e indicando outros caminhos possíveis para a humanidade.

Em seu processo de constituição, desde a Independência, passando pela Revolução Nacionalista de 1952 até a ascensão do Governo Morales, o Estado criollo boliviano esteve empenhado em um processo de castelhanizar a população de forma geral, extinguindo a herança indígena. No período inicial da República, Álvaro García Linera define como “cidadania de casta”, o resultado político dessa negação. Segundo Linera (2010, p. 102), no “âmbito do Estado, seja sob orientação liberal ou conservadora, os indígenas constituíam sua externalidade". Inclusive, o ódio em relação aos indígenas e às suas tradições comunitárias foi muitas vezes o que unificou as frações das classes dominantes em vários momentos de crise. O Estado republicano é um Estado de exclusão, no qual o indígena não é considerado um cidadão, a despeito daquele ter se edificado sobre os ombros desse indígena, de sua “extorsão histórica”, de sua "alienação fundadora”, convertendo suas "potências vitais" em "forças separadas e depois alheias que se voltam contra ele para domesticá-lo e submetêlo” (LINERA, 2010, p. 151).

Desde fins do século XIX, quando a Bolívia consolidou sua economia extrativista, houve uma ofensiva feroz contra a comunidade indígena em particular. Com o Decreto 20 de 
Marzo de 1866, o então ditador conservador Mariano Melgarejo (1864-1871) levou as terras das comunidades e ayllus a leilão público, o que gerou também massiva resistência. Mesmo com sua queda, os esforços em extinguir a comunidade indígena continuaram sob um discurso liberal e modernizante através da defesa do parcelamento individualizado da terra, transformando os indígenas em pequenos proprietários. A Ley de Exvinculación de 1874, já no Governo de Tomás Frias Amettler (1872-1873 e 1874-1876), declarou a extinção da comunidade - ao menos do ponto de vista jurídico.

Na Guerra Civil de 1899, que opôs conservadores do sul e os liberais do norte, Zárate

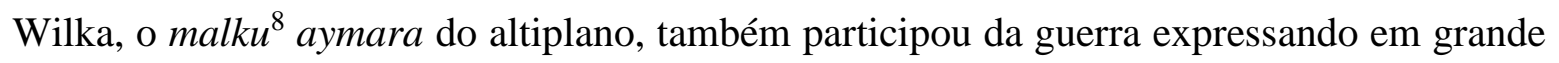
medida as tensões vividas principalmente no campo diante do avanço da economia extrativista e latifundiária e sua política de extinguir a comunidade. Segundo Rivera Cusicanqui (2010, p. 85), "los territorios comunales de los ayllus veían progresivamente constreñido su espacio de reproducción y desmantelado su universo ideologico”. O monopólio da terra, do mercado e do poder político pelas elites deixou os indígenas encurralados. O projeto liberal modernizador não os contemplava, pois partia de uma natureza excludente e colonial. Wilka colocou essas contradições em evidência e, apesar de ter iniciado a guerra ao lado dos liberais, depois desenvolveu objetivos autônomos, tais como: "a restituição das terras comunais usurpadas; a luta contra a ofensiva latifundiária; a defesa de um governo índio; o não reconhecimento das autoridades liberais e conservadoras’ (IDEM, p. 85-86).

Ainda segundo Rivera Cusicanqui, "la rebelion de Wilka fue quizás la ultima rebelion india autonoma del periodo republicano" (IDEM, p. 86). Ao fim, os indígenas foram derrotados e dizimados demarcando o fim de uma época. A nova República que se instaurou com a vitória liberal assentou-se sobre uma Bolívia mineradora e imbuída pelo darwinismo

\footnotetext{
${ }^{8}$ Malkus são as autoridades comunais.
} 
social. Os indígenas tornaram-se alvos de nova missão civilizatória, fadados a desaparecer. O progresso criollo representava o seu extermínio. Para tanto, não por acaso, nesse período, houve significativos investimentos na centralização e profissionalização do Exército Nacional, implementou-se o serviço militar obrigatório, foi criada a polícia rural (que acabou subordinada ao coronelismo local), e incrementaram-se as expropriações de terras comunais tendo por base a Ley de Exvinculación de 1874, citada anteriormente, que aboliu a comunidade indígena. No esteio dessas ações, a classe latifundiária pôde se apropriar de tais terras e os indígenas tiveram de migrar para as cidades ou se submeter às péssimas condições de trabalho no campo. Quando migravam para as cidades, eram proibidos de expressar sua identidade cultural ou reproduzir seus costumes e valores. A eles era negada a condição mais elementar de cidadania, pois sequer eram reconhecidos como sujeitos.

Entre os anos 1910 e 1930, ocorreram várias rebeliões no altiplano em resposta ao governo liberal, que podem ser denominadas como movimento dos “caciques-apoderados" (RIVERA CUSICANQUI, 2010, p. 95). Depois de um período de silenciamento e atomização da resistência indígena por conta do massacre operado para destruir a rebelião de Wilka no final do século XIX, a partir dos anos 1910, pode-se observar um lento processo de reestruturação das lutas indígenas com a explosão de algumas rebeliões, ainda que parcamente documentadas.

As tentativas de abolir a comunidade indígena acabaram gerando, como mecanismo de defesa, a "revitalización de los sistemas de autoridad comunal tradicional” (IDEM, p. 94-950), que tem como base estrutural o ayllu andino. Os “caciques-apoderados” eram os malkus e jilaqatas $^{9}$ dos ayllus do Altiplano que passaram a assumir funções não mais restritas aos aspectos comunais, mas atuavam como intermediários entre a comunidade e o Estado, resgatando um lugar assumido por seus antepassados no período colonial. O programa de

\footnotetext{
${ }^{9}$ Assim como os malkus, os jilaqatas também são autoridades comunais. 
reformas dos caciques pode ser sintetizado da seguinte maneira: restituição das terras comunais, abolição do serviço militar obrigatório, supressão dos tributos coloniais ainda existentes, representação indígena no Congresso e em instâncias de poder local, estabelecimento de escolas comunitárias e acesso livre ao mercado.

Ainda segundo a argumentação de Rivera Cusicanqui (2010), durante décadas, a Bolívia foi conduzida por uma elite oligárquica interessada basicamente no extrativismo mineral (estanho) e na exploração do campo, entregue aos latifundiários que, por sua vez, estabeleciam relações servis de produção com os camponeses ${ }^{10}$. Dessa forma, havia uma profunda dependência em relação ao mercado internacional, particularmente com os EUA. O projeto dependentista das elites se consolidou em uma lógica extremamente onerosa para o Estado, pois toda a extração estava delegada às empresas estrangeiras e o país era extremamente vulnerável à cotação dos preços no mercado internacional.

Segundo Everaldo de Oliveira Andrade (2007, p. 27), o Estado nacional era um mero instrumento nas mãos das três famílias que estavam por trás da exploração do estanho: Simon I. Patiño, em 1931, detinha 62\% do volume de exportações do estanho; Mauricio Hothschild, em 1938, 26\% do controle das exportações e Carlos Aramayo, em 1934, $10 \%$. Consequentemente, eram essas mesmas famílias que também controlavam a exploração do petróleo e as ferrovias, além de outros serviços de significativa importância.

Para Andrade, a Guerra do Chaco, que estourou entre 1932 e 1935, é central para compreender as raízes da Revolução de 1952, pois alçou o movimento operário como uma resposta ao recrudescimento das contradições raciais, sociais e econômicas existentes no país nos tempos difíceis da Segunda Guerra Mundial (1939-1945) ${ }^{11}$. O fim da Guerra do Chaco se

\footnotetext{
${ }^{10} \mathrm{O}$ imposto ponguaje, por exemplo, funcionava como uma escravidão por dívida.

11 A Guerra do Chaco ocorreu entre a Bolívia e o Paraguai, entre 1932 e 1935, como consequência da disputa territorial do Chaco Boreal, devido à descoberta de petróleo naquela região do sopé dos Andes. O que era para ser uma guerra rápida acabou se tornando uma das maiores guerras da América do Sul no século XX, com 60 mil bolivianos mortos de um lado, e 30 mil paraguaios do outro. A Bolívia acabou perdendo o território que foi anexado pelo Paraguai.
} 
caracteriza, portanto, como um período de profunda crise econômica e crescente mobilização popular, tendo como destaque a organização sindical.

Se até os anos 1950, a base dos movimentos sociais reivindicatórios ainda era fundamentalmente comunitária, a partir de então, um novo sujeito assumiu o protagonismo: os sindicalistas mineiros. Durante as décadas de 1930 e 1940, multiplicaram-se os núcleos de discussão política que, por sua vez, foram se aglutinando e convergindo para um novo formato de partidos políticos. Nas cidades, surgiram o Partido Obrero Revolucionario/POR, de orientação trotskista; o Partido de Izquierda Revolucionario/PIR, de orientação stalinista; e o Movimiento Nacionalista Revolucionario/MNR, de orientação nacionalista e antioligárquico, para citarmos os mais importantes.

Já no campo, houve uma rearticulação das lutas com a tática da "huelga de brazos caídos" nas haciendas elaborada a partir de uma articulação entre colonos e setores urbanos radicalizados. O governo de Gualberto Villarroel López (1943-1946) foi o clímax do movimento popular grevista e marcou também o Primer Congreso Indigena (1945), de nível nacional, reunindo centenas de malkus, jilaqatas e alcaldes índios com um efeito simbólico bem representativo. Villarroel havia participado da Guerra do Chaco e representava uma geração de jovens oficiais imbuídos pelo nacionalismo que tinha como propósito reformar a estrutura política oligárquica boliviana. Ascendeu ao poder por meio de um golpe de Estado e governou em coalizão com o Movimiento Nacionalista Revolucionario/MNR.

Com tom paternalista e escuta às demandas indígenas, atendeu a algumas determinações do Primer Congreso Indigena, acabando com o pongueaje e procurou manter um canal aberto de diálogo entre o Estado e as comunidades indígenas retomando, assim, uma velha tradição existente de relações estatais-comunitárias nos moldes corporativistas. Não à toa, o presidente era chamado de "Tata" (pai, em aymara). Desse modo, o governo apoiado pelo MNR representava uma ruptura com a concepção oligárquica de que os 
indígenas deveriam ser extintos e passou a reconhecê-los como sujeitos com demandas que precisavam ser atendidas.

Por outro lado, tal aproximação com o campesinato indígena favoreceu em grande medida para o linchamento e enforcamento de "Tata" em 1946, após a invasão do Palacio Queimado, por uma multidão formada pela plebe urbana, insatisfeitos com a condução do governo. Para Rivera Cusicanqui, a fúria popular que matou Villarroel expressa a "paranoia colectiva del asedio índio”, “de la memória de los ciclos rebeldes de Túpac Katari y Zárate Willka”. Sua morte foi celebrada como a "muerte del padre de los índios”, e com isso, inaugurou-se uma nova onda de perseguições e busca pelo extermínio da "indianada" e centenas de focos rebeldes (RIVERA CUSICANQUI, 2010, p. 123).

Do ponto de vista das resistências, diferentes ações se seguiram no final da década de 40. A resposta do Estado a tais focos de insurgência foi a repressão violenta cuja maior expressão foi o Massacre de Catavi, em 1942, que ficou gravado na memória do movimento operário boliviano, quando os mineiros, junto às suas mulheres e crianças, foram massacrados indiscriminadamente depois de uma passeata que contava com mais de oito mil pessoas. O Massacre serviu para impulsionar definitivamente, sob a liderança do POR, o movimento mineiro. Em 1946, depois de um grande Congresso, foi lançado um conjunto de teses que marcava uma posição bem definida do movimento operário boliviano fortemente inclinado à Revolução Socialista - as Teses de Pulacayo.

A repressão acabou por atingir também setores mais privilegiados e contribuiu para uma convergência entre os movimentos indígenas comunitários e o MNR com a criação das primeiras células indígenas camponesas na órbita nacionalista. A partir daí a influência do MNR foi crescendo sobre as lideranças indígenas e os movimentos camponeses. Tal aproximação colaborou também para um afastamento do movimento camponês de pautas que diziam respeito mais especificamente aos interesses comunitários (como a restituição das terras comunitárias, por exemplo) em prol de uma agenda mais voltada à "modernização" do 
país, com a criação de um mercado mais inclusivo, a ampliação do sistema educacional, a reforma agrária, entre outros. O movimento operário urbano foi assumindo o protagonismo e, apesar de uma anunciada aliança operário-camponesa, perdurava a visão civilizatória sobre o campo. Concretamente, o projeto de mestiçagem do MNR era a adoção unilateral dos valores, da língua, dos modos de pensamento tipicamente urbanos, excluindo qualquer forma de multiculturalismo ou multilinguismo. Nessa lógica, era preciso transformar os indígenas em camponeses e manter suas lideranças sob controle, de modo que todo o conteúdo étnicocomunitário fosse gradativamente colonizado pelo discurso da "igualdade cidadã ”. Por isso, para Rivera Cusicanqui, "el triunfo de 1952 sorprenderá al campesinato índio con el fin, momentâneo, de su utopia comunitária” (IDEM, p. 129).

A Revolução Nacionalista de 1952 marcou o colapso da República Oligárquica provocado pelo insustentável paradoxo de um governo que pretensamente deveria expressar a vontade geral, mas que seguia silenciando e exterminado a voz indígena. Como aponta Linera (2010, p. 105), em 1952, as classes populares e indígenas, armadas, foram à luta para conquistar aquilo que consideravam ser seu de direito. A despeito de todos os esforços de cooptação, a cidadania emergente desse processo teve como ponto de partida a "ação autônoma da plebe" e o "sindicato" como principal sujeito político de organização popular. Nesse cenário, a "cidadania de castas" cedeu lugar a uma "cidadania corporativa", na qual o grau de democratização do Estado passou a estar relacionado à sua permeabilidade à intrusão sindical e não necessariamente a quantidade de votos. É o sindicato que viabilizava a cidadania. Ainda que não diretamente, essa perspectiva de uma estrutura corporativista mediada pelo sindicato foi também herdeira das tradições comunais-agrárias, haja vista que a partir destas, compreendeu-se uma concepção de cidadania não individualizada, na qual se fundiram direitos políticos e direitos sociais.

Victor Paz Estenssoro, líder do Movimiento Nacionalista Revolucionario/MNR, foi alçado ao poder em 1952 e, na sequência, buscou construir um governo de coalisão entre 
setores reformistas e as classes populares organizadas. Na ocasião, havia-se formado a Central Obrera de Bolívia/COB com ampla representatividade e houve esforços no sentido de se criar um co-governo entre movimentos sociais e o Estado recém conquistado.

\begin{abstract}
Os dias de insurreição revolucionária que abalaram a Bolívia entre 09 e 11 de abril representavam o ápice de um longo processo em que as massas populares tomaram em suas próprias mãos a história do país. Suplantando os planos, os preparativos e as conspirações cotidianas da maioria dos grupos e dos partidos políticos, a massa revolucionária tornara-se personagem central. É esse personagem, de mil faces e mil braços, de ações sincronizadas e espontânea, que agiu e realizou, sem deixar muitos registros de suas pequenas ações, a grande insurreição de abril de 1952. Por esse motivo, 1952 não foi apenas um momento político de profundidade e dimensões revolucionárias, mas representou uma mudança de grau e de métodos da luta política na Bolívia (ANDRADE, 2007, p. 74).
\end{abstract}

Porém, nessa dimensão de participação cidadã via sindicatos, não havia ainda uma demanda consolidada pela democratização do executivo propriamente dita. Ao contrário, a compreensão do poder político estatal como atribuição personalizada de uma liderança reafirmava ainda a estrutura política nacional-colonialista. Nos anos 1950, as classes populares e indígenas não se viam governando de fato: "a democratização do espaço político é meramente interpeladora, não executiva; isto é, a plebe se sente com o novo direito de falar, de resistir, de aceitar, de pressionar, de exigir, de impor um rosário de demandas aos governantes, mas jamais poderá ver a si mesma no ato de governar” (LINERA, 2010, p. 106 [grifo meu]).

O processo insurrecional que levou à Revolução de 1952 envolveu uma ampla mobilização operário-camponesa que foi determinante para impor a capitulação da ordem oligárquica anterior. Porém, tão logo estabelecida a Pax Revolucionaria, as tentativas de controle das forças sindicais populares também se efetivaram. Houve, em um primeiro momento, um incentivo à sindicalização massiva das milícias operárias e camponesas, mas, em seguida, foram implementadas medidas com intuito de cercear sua autonomia, dentre as 
quais Rivera Cusicanqui (2010, p.143) cita ainda o incentivo às disputas faccionais, o prebendalismo ${ }^{12}$, o clientelismo, o caudilhismo e a corrupção. Em suas palavras, "todo el intento de autonomía ideologica es sistematicamente marginalizado, y se subordina a los sectores potencialmente conflictivos en un proceso de degradación que termina borrando los contornos democráticos iniciales de la incorporación campesina al proyecto movimientista" (IDEM, p. 143).

Após 1958, teve início um período de maior polarização ideológica e fragmentação do movimento, com o aumento das tensões entre setores mais burocratizados já flutuando na órbita mais direta do MNR e setores mais radicalizados aproximando-se da COB.

Nos anos 1960, consumou-se a crise e foi aberto um caminho para que a direita, apoiada em um bloco empresarial-militar, derrubasse o governo nacionalista do MNR e, com General Barrientos (1966-1969), rumasse em direção ao endurecimento do regime, à abertura ao capital estrangeiro e ao controle definitivo sobre o campo com a assinatura do Pacto MilitarCamponês. Este último tinha por objetivo substituir a articulação sindicato-partido-Estado estabelecido durante a Revolução Nacionalista por uma relação direta com os camponeses, ancorada no Exército e no personalismo carismático do próprio Barrientos, configurando-se, assim, um Estado Paternalista. Porém, mesmo com tais esforços, já em seu governo, muitas dissidências se acumularam denunciando as medidas implementadas, como a brutal repressão ao movimento mineiro - vide os massacres no complexo Catavi-Siglo XX - e algumas medidas de ajustes fiscais.

A morte prematura do General Barrientos, em 1969, permitiu que o cenário se radicalizasse ainda mais: de um lado, a COB começou a se reestruturar e recuperou força e popularidade entre os movimentos sociais; de outro, a posição das direitas se endurecia com seus objetivos de retornar à ordem pré-52. A situação ficou bastante tensa e os enfrentamentos

\footnotetext{
${ }^{12}$ Prebendalismo é expressão do patrimonialismo, no qual os bens públicos são utilizados como moeda de troca para o atendimento a interesses privados.
} 
tornaram-se cada vez mais frequentes. Finalmente a COB convocou uma greve geral e a ditadura foi obrigada a convocar eleições.

Com o General Juan José Torres do MNR no poder foi proposto novamente um cogoverno com os operários. Porém, a postura do novo governo era ambígua, pois ainda que se tratasse de um governo disposto a compor uma frente antifascista contra o eixo empresarial e da agroindústria apoiado por parte do aparato militar e das classes médias altas, o nacionalismo de Torres também era uma forma de frear os movimentos sociais impedindo uma possível radicalização socialista.

Sendo assim, muitas polêmicas se seguiram aos esforços de compor esse co-governo, já que para amplos setores da $\mathrm{COB}$ era fundamental não cometer os mesmos erros do passado e, se, por um lado, acabaram aceitando alguns ministérios oferecidos pelo governo, por outro, tentaram se afastar de um lugar de linha auxiliar. Nesse sentido articulou-se um poder paralelo que deveria responder pela condução das políticas nacionais: a formação de um “parlamento operário-popular”, a Assembleia do Povo, espaço deliberativo e executivo por meio do qual se exerceriam a democracia direta e o poder popular.

As tentativas do governo de trazer o movimento independente da COB para dentro do Estado foram infrutíferas. Ainda que o nacionalismo de Torres incorporasse muitas pautas importantes das classes populares e indígenas, tais como a estatização dos ramos principais da economia, o enfrentamento ao imperialismo e o compromisso com políticas sociais, a ideia da Assembleia do Povo se tornou cada vez mais forte a ponto em que, em maio de 1971, foi realizada a Assembleia Nacional do Povo em uma realidade na qual estava colocada uma dualidade de poderes. A experiência da Comuna de La Paz, como assim também foi chamada, foi objeto da tese de Everaldo Andrade que foi publicada com o título Bolívia: Democracia e Revolução: A Comuna de 1971, no qual o autor analisa com maior profundidade o que muitos chamaram de o "primeiro soviete da América Latina” (COGGIOLA in ANDRADE, 2011, p. 10). Andrade considera a Assembleia de 1971 como uma "síntese das tradições 
internacionais da democracia, dos Conselhos Operários com as práticas e tradições locais de democracia direta e formas de autogoverno" (ANDRADE, 2011, p. 12).

Ainda segundo Andrade (2011), tendo como base social a pequena burguesia, a agroindústria cruceña e boa parte do comando militar, e contando com o apoio dos EUA e das ditaduras do Cone Sul, engendrou-se uma guerra civil que derrubou Torres. A prisão de Hugo Banzer, umas das principais lideranças desse movimento, foi o estopim para o início da ação militar que, em poucos dias, mesmo com a resistência armada dos trabalhadores em muitas cidades, instituiu uma nova ordem política ditatorial com o fechamento das universidades, o estabelecimento da censura, a perseguição e morte das lideranças operárias e populares (contando, inclusive, com o apoio da Operação Condor das ditaduras do Cone Sul) e um novo tempo para a história desse país.

Banzer, depois tornado ditador, só foi derrubado em 1978 devido às pressões desde abajo, seguindo-se um período de profunda instabilidade política e de crise estrutural de representatividade do regime republicano. Diante de tal crise, os movimentos populares e indígenas reorganizam-se, sendo que dessa vez pautaram um novo horizonte político, rumo ao Estado com o objetivo de transformá-lo radicalmente

\footnotetext{
Por isso, eu penso que, se nós vamos fazer uma revolução no futuro, nosso governo terá que ser de nossa origem, terá que ser operário, terá que ser camponês. Só assim teremos a garantia de que nós estaremos no poder. Porque só aqueles que sabem perfurar uma rocha, só aqueles que sabem o que é trabalhar e ganhar o pão de cada dia com o suor de seu rosto, é que poderão fazer leis para controlar e proteger a felicidade da grande maioria que é explorada (CHUNGARA in VIEZZER, 1982, p. 45).
}

\section{O Tempo Curto: Indígenas rumo ao Estado}

Anos 1970. A conjuntura global foi marcada pela ascensão de novas subjetividades pósestruturalistas, como os movimentos ecologistas, feministas, antirracistas, étnicos, em defesa 
dos direitos humanos, da autodeterminação dos povos, pós-coloniais. Na Bolívia, no cenário de rearticulação dos movimentos sociais, uma das mais significativas organizações que surgiram foi a Federação Camponesa Tupac Katari. Tratava-se de um movimento que procurava representar o campesinato indígena boliviano e que tinha duras críticas aos tradicionais movimentos de esquerda que jamais contemplaram a questão étnica em suas plataformas de luta. O sindicalismo katarista denunciava “a exploração econômica e política dos povos indígenas, o genocídio cultural e a discriminação que os privava de toda a vida pública" (ANDRADE, 2007, p. 167).

No mesmo esteio, em La Paz e El Alto, várias organizações aymaras assinaram um documento de grande repercussão intitulado "Primer Manifesto de Tiahuanaco"13" (1973) no qual se sintetizam algumas das principais propostas oriundas dessa crescente "indianização da política", reivindicando valores ancestrais dos povos originários e empreendendo a partir daí um processo de descolonização política, econômica e cultural.

O Manifesto foi expressão de um primeiro momento de uma nova geração de movimentos populares e indígenas que reconheciam a potência inscrita em seu mundo decolonial e como, a partir dele, era possível de fato postular outros rumos possíveis para a Bolívia. Os kataristas e indianistas foram aqueles que deram voz ao ressentimento índio diante da discriminação racial e cultural e do rebaixamento de sua cidadania. Os massacres protagonizados pelo Estado, como o de Tolata, de Todos os Santos, de Colquiri, também evidenciavam o quão distante o regime vigente se encontrava dos reais interesses dessa população. Por outro lado, os bloqueios, a tática do cerco e a resistência a tais ações arbitrárias sinalizavam, de igual maneira, a força ainda presente de tradições milenares que se reinventavam nas lutas do presente. A comunidade indígena seguia constituindo-se como

\footnotetext{
${ }^{13}$ A civilização Tiahuanaco é uma das principais precursoras do Império Inca, constituiu-se como um poder regional no território que hoje corresponde à Bolívia por mais de cinco séculos e cujo apogeu se deu entre os anos 300 e 1000. Seu principal sítio arqueológico localiza-se próximo a cidade de La Paz onde até hoje se realizam cerimonias religiosas e políticas.
} 
um dos eixos estruturadores dessa re-existência que potencializava as lutas populares e alimentava as outras possibilidades de ver o mundo. Ao mesmo tempo, ocorria o esvaziamento dos movimentos de esquerda tradicionais, como o dos mineiros, devido à repressão, ao aprofundamento das desigualdades no país e ao esgotamento das minas que fez com que muitos trabalhadores tivessem de ir para outras regiões no campo ou nas cidades em busca de emprego, para fugir da fome.

O processo de etnização da política deve ser compreendido de maneira ampla e complexa, pois há uma diversidade étnica e ideológica que abarca diversas perspectivas sobre o passado, as formas por meio das quais as lutas que deveriam se travadas no presente e os horizontes futuros. Enquanto alguns movimentos caminharam para uma perspectiva neoliberal do multiculturalismo como veremos adiante, outras gradativamente foram assumindo um viés de maior ruptura com o governo colonial e postularam alternativas antissistêmicas. Para este trabalho conferi ênfase nas perspectivas que se desdobraram no segundo caso, sem deixar de fazer referência a outras possibilidades e sem ter qualquer pretensão de esgotar as múltiplas visões existentes (inclusive das que negam o Estado em um sentido mais amplo e irrestrito).

Desse modo, Andrade (2007) demonstra como que, ao passo em que se agudizava a crise generalizada nas instituições formais, sejam elas públicas ou privadas, crescia também o desejo de alguns desses movimentos populares e indígenas de participar de forma mais categórica nas esferas de decisão, podendo assim operar algumas mudanças de caráter mais ou menos radical. Com uma tentativa de responder a tais pressões, a partir dos anos 1980 e 1990, aumentou o apelo retórico em favor da igualdade, liberdade e soberania, bem como do multiculturalismo e pluralismo por parte das elites criollas. Porém, essas últimas tinham como objetivo neutralizar e fragmentar as demandas e aspirações populares e indígenas que, naquele momento, iam em um sentido de exigir com maior contundência o reconhecimento de sua cidadania plena e de uma outra lógica de mercado que de fato os incluísse. Em vez do 
reconhecimento dessa condição de sujeito político que pleiteia direitos e propõe outras formas de conceber o mundo, houve ainda uma tentativa de adotar medidas culturalistas e assistencialistas sem maior impacto sobre essas populações. Com uma retórica pós-moderna e com uma base social indígena mais conservadora, foi possível resumir as demandas indígenas a um discurso em prol da etnicidade, esvaziando o reconhecimento do outro enquanto sujeito e essencializando ou ornamento sua condição em um sentido puramente estético. Dessa forma, foi possível, mais uma vez, reduzir a maioria da população em uma minoria estereotipada que não correspondia à realidade.

Como parte desse contexto e, mais particularmente, como reflexo da política de repressão do Estado à produção da coca surgiu o movimento cocaleiro de El Chapare, no Departamento de Cochabamba. Defendida como planta sagrada e milenar, a coca tornou-se símbolo da resistência indígena diante dos interesses imperialistas e dos governos neoliberais. Enquanto isso, desde as "terras baixas" amazônicas, ainda em 1990, ocorreu a I Marcha Por La Vida Dignidad y Territorio protagonizada por guaranis de diferentes grupos em repúdio às ações de madeireiras e de pecuaristas em suas terras de origem, exigindo a demarcação das mesmas, a soberania sobre o território e o autogoverno segundo princípios e normas tradicionais.

Como consequência da ascensão desses movimentos e também de uma política global que caminhava no sentido de reconhecer as "minorias" excluídas de representação liberal, houve na Bolívia alguns avanços significativos referentes à questão indígena do ponto de vista da conquista de direitos fundamentais. Contudo, os limites evidentes dos governos no sentido de atender às demandas crescentes, somado ao impacto econômico-social do neoliberalismo, levaram a um período de levantamientos populares, no qual as classes populares e indígenas foram às ruas reivindicar suas bandeiras, constituindo-se enquanto poderes paralelos que não mais respondiam ao Estado. Os dois principais episódios foram a Guerra da Água, em 2000, em Cochabamba, em resposta à tentativa do governo de privatizar 
a água, e a Guerra do Gás, em 2003, em La Paz/El Alto em resposta ao aumento dos impostos e ao projeto do governo de exportar o gás e outras fontes naturais através do Chile - inimigos eternos dos bolivianos por ter-lhes anexado sua única saída para o mar. Ambas as insurreições foram vitoriosas politicamente, porém, deram-se às custas de muitas vidas devido à repressão do Estado.

$\mathrm{Na}$ esteira dessa efervescência social, coube ao Movimiento al Socialismo/MAS, que havia sido criado em 1995 como Instrumento Político para Soberania dos Povos, sob o protagonismo dos cocaleiros de El Chapare, o papel de constituir um bloco histórico capaz de agregar diversos setores populares e indígenas descontentes em prol de uma candidatura comum que representasse o protagonismo indígena na tomada de decisões, explicitando a necessidade de modificar as estruturas que regiam o país, a começar pela própria Constituição. Evo Morales Ayma, que já havia se destacado como sindicalista, presidente de seis federações cocaleiras desde 1996, eleito senador pelo MAS em 1997, que participou ativamente das manifestações de rua durante os anos 1990 e 2000, foi escolhido como candidato à presidência. Perdeu por 1,6\% as eleições de 2002 e, em 2005, foi eleito com 53,74\% dos votos (ELECTORAL GEOGRAPHY, 2002 e 2005).

Com a eleição de Evo Morales, o MAS já reunia um conjunto muito mais amplo de movimentos sociais que os que deram impulso a sua formação, incorporando as classes médias urbanas e até mesmo o pequeno e médio empresariado. A fórmula do poncho e da gravata representado pelo presidente indígena e o vice-presidente, Álvaro García Linera, respectivamente, expressa um esforço em agregar diferentes setores da sociedade boliviana em prol de um projeto comum de transformações orientado a favorecer as classes populares e indígenas. Na prática, essa premissa tendeu a uma postura mais moderada e conciliatória do MAS, afastando-se em certa medida do radicalismo indígena que lhe deu origem. Havia, nesse sentido, um duplo papel a ser cumprido por este Instrumento Político: o de mobilizar e, ao mesmo tempo, moderar os movimentos sociais (Cf, ANDRADE, 2007). 
Tal como defendido na campanha, uma das primeiras medidas do governo foi convocar uma Assembleia Nacional Constituinte/ANC para que os povos originários, finalmente, pudessem participar de sua idealização. A ANC foi inaugurada em Sucre, capital jurídica da Bolívia $^{14}$, em 06 de agosto de 2006, contando com a participação desses novos atores políticos, isto é, as classes populares e indígenas, devidamente caracterizadas segundo os seus respectivos costumes e que carregavam consigo contribuições inovadoras para redefinir o Estado e estabelecer, de fato, um novo Pacto Social. Segundo Salvador Schavelzan (2010, p.2), pela primeira vez na história da Bolívia, os constituintes tinham a "fisionomia das maiorias do povo”. Além desses, os representantes da Meia Lua boliviana, referentes aos Estados de Beni, Pando, Santa Cruz e Tarija, regiões que concentram as principais riquezas naturais do país e com forte protagonismo de setores oligárquicos, também se fizeram presentes.

Desde a constituição do Pacto de Unidade, em 2002, entre diversos movimentos populares e indígenas em favor de um bloco histórico unificado na candidatura de Evo Morales, havia se elaborado uma proposta de Constituição que foi defendida pelo MAS tanto na "agenda de outubro", na ocasião da Guerra do Gás de 2003 e que orientou as eleições de 2005, quanto nos trabalhos da Constituinte. Uma das principais metas dos constituintes deste grupo era aprovar o caráter Plurinacional e Comunitário do Estado Boliviano.

A "plurinacionalidade" não era um conceito novo. Ao contrário, os limites do modelo monocultural do Estado-Nação já vinham sendo questionados em diversas partes do mundo e vimos como, na década de 1990, já se discutia com maior intensidade o caráter multiétnico da população boliviana e a necessidade de se criar mecanismos que garantissem maior visibilidade às diferenças existentes no interior do Estado. Porém, se por um lado a proposta

\footnotetext{
${ }^{14}$ A Bolívia possui duas capitais: Sucre e La Paz. Isso se deve à Guerra Federal (1898-1901), uma guerra civil que opôs os liberais de La Paz (norte) contra os conservadores de Sucre (sul) em disputa pela liderança da Bolívia. Resultou na derrota do sul e, com isso, na mudança da capital do país, ou pelo menos dos Poderes Executivos e Legislativos, para La Paz. Sucre permaneceria apenas como sede do Poder Judicial.
} 
era se afastar do "monoculturalismo da assimilação" que visava integrar o indígena à vida nacional de forma colonial e silenciadora, como foi na Revolução de 1952, por outro, também procurava se diferenciar de um multiculturalismo que reconhecia a diferença desde que "continue subordinada, restringida", como foi na ocasião das reformas da década de 1990 (SCHAVELZON, 2010, p. 5).

Para os representantes do MAS e do Pacto de Unidade, reivindicar a plurinacionalidade e comunitarismo na Constituinte tinha profundas implicações, pois envolvia: denunciar o colonialismo interno e apontar para os mecanismos de descolonização e retratação histórica necessários; resgatar as tradições comunitaristas dos ayllus e organizações indígenas; defender a autodeterminação dos povos originários e a autogestão; incorporar a noção de direitos coletivos (e não apenas individuais) e de pluralismo jurídico; diversificar as práticas democráticas, incluindo procedimentos quantitativos e qualitativos de participação e de tomada de decisões; estabelecer novas territorialidades que pudessem reconhecer os diferentes tipos de autonomia; incluir novos sujeitos políticos no pacto social, como a natureza e os "seres da terra"; determinar o fim do latifúndio e garantir o controle dos recursos naturais pelo povo, entre outros.

Para Boaventura de Souza Santos (2010, p. 23), emergia dessas pautas um "novo constitucionalismo" que procurava dar respostas ao embate entre uma constitucionalidade invisível dos ayllus, povoados, markas $^{15}$ e territórios originários e a constitucionalidade moderno-liberal que até então havia orientado o Estado-Nação. Porém, foi um tortuoso caminho combinar ambas as tradições.

A paralisia da Assembleia Constituinte levou a um aumento das tensões entre a oposição e as classes populares e indígenas que só se resolveu com a convocação de um referendo revogatório presidencial. Realizado em 2008, Morales saiu vitorioso com 67,43\%,

${ }^{15}$ É um espaço local, transcomunitário, que abarca vários ayllus. 
porcentagem maior da que tinha recebido quando eleito em 2005 (ELECTORAL GEOGRAPHY, 2008).

A Nova Constituição Política do Estado/NCPE foi finalmente encaminhada a referendo no dia 25 de janeiro de 2009. Foi aprovada com 61,43\% dos votos, com uma participação de mais de 90\% dos habilitados a votar (ELECTORAL GEOGRAPHY, 2009). Ao lado dos cânones do constitucionalismo liberal, a Nova Constituição Política do Estado/NCPE inovou no sentido de reconhecer efetivamente os povos originários e seu conjunto de valores e tradições, bem como a necessidade de se avançar na desconstrução do colonialismo interno. Foram reconhecidas as línguas indígenas como idiomas oficiais da nação (artigo 5); agregou aos símbolos oficiais, a whipalla, por exemplo (artigo 6); estabeleceu princípios ético-morais inspirados nas tradições andinas tais como a tríade incaica ama qhilla (não seja ocioso), ama llulla (não seja mentiroso) e ama suwa (não seja ladrão), além do suma qamaña (viver bem), ñanderejo (vida harmoniosa), teko kavi (vida boa), ivi maraei (terra sem mal) e qhapaj ñan (caminho ou vida nobre) (artigo 8); institucionalizou a interculturalidade (artigo 178), a pluralidade jurídica (reconhecendo o sujeito coletivo) e a proporcionalidade para ocupação de cargos; ampliou a democracia para formas diretas, participativas e comunitárias (artigo 11), estabeleceu critérios mais específicos para a defesa e preservação da Pachamama (artigos 380 a 392), entre outros aspectos.

A NCPE pode ser considerada uma das cartas mais radicais da América Latina e única na história ocidental, no que diz respeito à regulamentação de um Estado multicultural, descentralizado, com autonomias e forte incremento à participação popular.

Segundo Linera, a Nova Constituição Política do Estado criada com significativa participação popular, de baixo para cima, e aprovada pelo voto popular, resulta na conformação do que define como um "Estado Integral" (LINERA, 2010a, p. 8-10 
), isto é, um Estado Plurinacional, autonômico ${ }^{16}$ e comunitário de direito que representa e integra toda a sociedade (compreendendo seus entes humanos e não humanos) e todas as dimensões da vida. Esse Estado é a ponte que levaria do capitalismo para o socialismo comunitário e, deste último, para o Bem Viver. Desse modo, em vez de estar pautado em um regime de propriedade, como o faz o Estado Moderno liberal, para Linera, o Estado Integral está comprometido com o livre acesso ao que é comum, a redistribuição dos excedentes do Estado para o âmbito comunitário e a uma economia plural.

Após a vitória sobre a oposição com a nova Constituição, começaram a surgir com maior intensidade as contradições dentro do próprio bloco histórico formado no âmbito do Proceso de Cambio. As divergências sobre quais caminhos o governo deveria seguir e quais estratégias assumir foram se constituindo como tensões criativas que abriram um novo campo de possibilidades. Segundo Linera (2010a), essas contradições só poderiam ser superadas mediante um processo de radicalização democrática que apontasse para uma ruptura revolucionária. Porém, será que isso seria realmente possível?

\section{Considerações finais}

Existem muitos aspectos do Governo Morales que foram deixados de lado nessa análise $^{17}$. O objetivo central deste trabalho foi o de recuperar um tempo de longa duração, milenar, que remonta à estruturação da comunidade indígena, e de que maneira esse aspecto

\footnotetext{
${ }^{16}$ A noção de autonômico refere-se a um Estado que reconhece e respeita as autonomias (desconcentração territorial).

${ }^{17}$ Para uma reflexão mais densa sobre os meandros do Governo Morales a partir do protagonismo indígena, mais particularmente a partir da atuação lideranças comunitárias da Cidade de El Alto, recomendo a leitura da minha tese de Doutorado, O Estado Plurinacional e Comunitário na Bolivia: As Lutas Populares e o Bem Viver a partir de El Alto (2019), resultado de um trabalho de pesquisa baseada em uma vivência em campo no ano de 2017 e na história oral de lideranças e ex-lideranças das juntas vecinales desta cidade que é considerada uma das mais combativas do país, responsável inclusive pela estabilidade política dos governos em curso.
} 
influencia na constituição dos movimentos indígenas ao longo de seus processos de reexistência ao Estado criollo, principalmente após a independência quando se evidencia a permanência do colonialismo e sua reprodução por parte das oligarquias que assumiram a condução da República. Para tanto, apoiei-me principalmente na mirada decolonial de Rivera Cusicanqui, Linera e Zavaleta que confere destaque para esse lugar protagonista das classes populares e indígenas na condução de seu processo histórico e constantes ressignificações de suas lutas. Na medida em que os limites do Estado criollo são expostos, observamos também como ocorre, a partir dos anos 1970, um gradativo processo de etnização da política que resulta em uma tomada de posição por parte de alguns movimentos indígenas de conquistarem o Estado e transformar suas bases moderno-coloniais. Tal processo culmina na eleição de Evo Morales em 2005 e na assinatura de um novo Pacto Social que redefine o país no sentido de implementar um Estado Plurinacional e Comunitário que oferece um novo horizonte de transformações, assim como enseja um conjunto de contradições.

Nos anos que se seguiram à implementação da Nova Constituição, a Bolívia avançou de maneira significativa na construção de uma realidade social mais comprometida com o atendimento das demandas históricas das classes populares e indígenas, pautando o Bem Viver como um horizonte político de transformações profundas no país; com uma ampliação significativa da representatividade e da paridade de gênero e racial; com as nacionalizações dos setores estratégicos que contribuíram para um aumento das receitas do Estado e a redistribuição dos recursos em diversos programas sociais e obras de infraestrutura; além de terem sido implementadas várias medidas que contribuíram na redução da pobreza e da desigualdade estrutural que assola o país desde sua formação (Cf. MORALES, 2016). Porém, a despeito dessas questões, não há consenso quanto aos caminhos que deveriam ser seguidos. Há uma diversidade considerável de posições quanto a essência desse Estado Plurinacional e Comunitário, bem como de quais deveriam ser os próximos passos para instituir, por exemplo, o Bem Viver como uma alternativa civilizacional de fato. 
Em 2016, a imagem do Presidente já se mostrava desgastada, como pode ser percebido no referendo realizado naquele ano, no qual Morales teve sua primeira derrota nas urnas perdendo para o "NO" à reeleição indefinida com 51\% dos votos (ELECTORAL GEOGRAPHY, 2016). Apesar do discurso, outro aspecto que contribuía para solapar muitas de suas bases era a dificuldade de romper com o paradigma extrativista ou neoextrativista para utilizar a expressão cunhada pela Ecologia Política de Gudynas (2012, 2017), Escobar (2005), Svampa (2017) e outros. Em 2019, o Governo sofre seu revés final, quando imerso em uma profunda crise, o Presidente foi obrigado a se exilar no México.

O episódio ocorreu após as eleições. Com uma manobra burocrático-administrativa, Morales pôde se candidatar para um quarto mandato como presidente e saiu vitorioso do pleito com 47.08\% (ELECTORAL GEOGRAPHY, 2019), porém, o resultado foi contestado em meio a vários protestos e acusações de fraude. O Presidente então decidiu recuar e concordou em realizar novas eleições conforme sugerido pela Organização do Estados Americanos/OEA. Porém, as Forças Armadas interviram, exigiram a renúncia do cargo e Morales decidiu acatar às pressões e seguir para o exílio para evitar maior derramamento de sangue tendo em vista as várias denúncias de perseguição, prisão e desaparecimento de lideranças do então governo.

A senadora da oposição Jeanine Áñez autoproclamou-se presidenta interina obedecendo a linha sucessória, uma vez que o Vice-Presidente, Álvaro García Linera, assim como os presidentes e vice-presidentes do Senado e da Câmara também renunciaram. Na

cerimônia de posse, Áñez declarou que a Bíblia tinha voltado ao Palácio junto a um novo corpo de ministros esteticamente diferente, sem alusões a vestimentas tradicionais características dos povos indígenas, tal como era a marca do governo anterior. Por meio de um decreto, os agentes das Forças Armadas foram isentos de responsabilidade penal até que 
se instalasse a normalidade no país. $\mathrm{O}$ enfrentamento nas ruas e a violência deixaram vários mortos e feridos, além de muitas lideranças desaparecidas ${ }^{18}$.

A ascensão de uma nova coalisão neoliberal na Bolívia acompanha também uma conjuntura mais ampla da América Latina de reascensão de governos de direita retomando a prioridade em um modelo predatório, excluindo-se as contrapartidas sociais. Nos anos 2000, a Bolívia havia acompanhado uma onda nacionalista popular que resultou em avanços significativos nos processos de democratização da democracia, de redução da miséria, de uma distribuição mais equitativa da renda, da ampliação de direitos e de uma maior cooperação Sul-Sul entre os países ${ }^{19}$. Contudo, em 2019 o país era um dos poucos remanescentes desse período. Ainda que muitos desses governos nacionalistas populares não tenham sequer afetado as estruturas econômicas, somente o deslocamento dos recursos para políticas sociais, já foi o suficiente para que as oligarquias regionais respondessem até mesmo por meio de golpes contra esses governos propiciando o retorno da agenda neoliberal no continente $^{20}$. Assim, com este golpe, Bolívia se une aos demais países que também sofreram

18 "Sedes do partido e de movimentos sociais se converteram em alvos. Assim começaram os sequestros, os ataques contra casas, as humilhações e os linchamentos, como a prefeita que foi humilhada e pintada de vermelho, ou o presidente do sindicato dos radialistas que foi amarrado em uma árvore. No dia 9 de novembro, cercaram e invadiram a Bolivia TV, sequestrando seus funcionários e mudando a programação para uma favorável ao golpe. Em Cochamba, um grupo de choque formado por motoqueiros cometeu diversos delitos pela cidade, incluindo vários ataques que foram registrados contra mulheres em vestimentas indígenas" (Cf. ORTEGA, Daniel. "Bolívia: Lições de um golpe de Estado (parte 1)". In: https://revistaopera.com.br/2019/11/26/bolivia-licoes-de-um-golpe-de-estado-parte-1/ $\quad$ consulta em 26/12/2019)

${ }^{19}$ Dos casos mais radicais, aos mais moderados, podemos citar: Venezuela, com Hugo Chávez (1999-2013; Bolívia, com Evo Morales (2006-2019); Equador, com Rafael Correa (2007-2017); Brasil, com Lula e Dilma Rousseff (2003-2016); Chile, com Michelle Bachelet (2006-2010 e 2014-2018); Argentina, com Nestor e Cristina Kirchner (2003-2015); no Peru, com Ollanta Humala (2011-2016); no Uruguai, com Pepe Mujica (2011-2016) e Tabaré Vazquez (2005-2010 e 2015-hoje); no Paraguai, com Fernando Lugo (2008-2012); na Nicarágua, com Daniel Ortega (2007-hoje); em El Salvador, com Mauricio Funez (2009-2014) e Sanchez Cerén (2007-hoje), em Honduras, com Manuel Zelaya (2006-2009), entre outros.

${ }^{20}$ Vide o golpe parlamentar sofrido por Dilma Rousseff, no Brasil, em 2016, em um contexto de crise, pósboom dos valores das commodities no mercado internacional. Porém, podemos citar também os golpes ocorridos em Honduras, contra o Presidente Manuel Zelaya em 2009, e no Paraguai, contra o Presidente Fernando Lugo em 2012. A crise da Bolívia de 2019 torna-se, assim, mais um capítulo dessa história. Em todos 
esses reveses. Os efeitos dessa nova conjuntura que se apresenta no continente ainda são incertos. Porém, isso não significa necessariamente que nesse novo cenário os movimentos indígenas recuarão simplesmente para a condição de profunda invisibilidade que caracterizava o período anterior. Resta saber como reagirão aos intentos de se reintroduzir um programa neoliberal no país.

\section{Referência Bibliográfica}

ACOSTA, Alberto. O Bem Viver: Uma Oportunidade para Imaginar Outros Mundos. São Paulo: Elefante/Autonomia Literária, 2016.

ANDRADE, Everaldo de Oliveira. Bolívia: Democracia e Revolução-A Comuna de La Paz de 1971. São Paulo: Alameda, 2011.

São Paulo: UNESP, 2007. . A Revolução Boliviana. Coleção Revoluções do Século XX.

BALLESTRIN, Luciana. América Latina e o giro decolonial. Rev. Bras. Ciênc. Polít., Brasília, n. 11, p. 89-117, ago. 2013.2 Disponível em: <http://www.scielo.br/scielo.php?script=sci_arttext\&pid=S010333522013000200004\&lng=pt\&nrm=iso>. Acesso em 05 mai. 2020.

BBC. Crise na Bolivia. Disponível em: https://www.bbc.com/portuguese/internacional-50458211. Acesso em 26 dez. 2019.

BRUCE, Mariana. O Bem Viver e a Reforma de Estado na Bolivia. In: SCHEIDT, Eduardo; ARAUJO, Rafael P.; MAIA, Tatyana (orgs.). Estado, Democracia e Movimentos Sociais no Mundo Contemporâneo. 1ed. Rio de Janeiro: Estudos Americanos, 2019, v. 1, p. 215-250.

O Estado Plurinacional e Comunitário na Bolívia: As Lutas Populares e o Bem Viver a partir de El Alto. Tese de Doutorado. Niterói: PPGH/UFF, 2019.

BRUCKMANN, Mónica. Mi sangre en mis ideas: dialéctica y prensa revolucionaria en José Carlos Mariátegui. Caracas: Fundación Editorial El Perro y la Rana, 2009.

os casos, observa-se, em seguida, a ascensão de coalisões neoliberais. Pela via eleitoral, vale destacar também o retorno das direitas conservadoras na Argentina, com Maurício Macri (2015-2019) e no Peru, com Pedro Pablo Kuczynski (2016-2018). 
CASANOVA, Pablo González. Exploração, colonialismo e luta pela democracia na América Latina. Rio de Janeiro: Vozes; Buenos Aires: Clacso, 2002.

Colonialismo Interno: Una Redefinición. In: La Teoria Marxista Hoy. Buenos Aires: CLACSO, 2006, pp. 409-434.

CASTRO-GÓMEZ, Santiago; GROSFOGUEL, Ramon (coords.) El giro decolonial: reflexiones para uma diversidad epistêmica más allá del capitalismo global. Bogotá: Siglo del Hombre/Universidad Central/Instituto de Estudios Sociales Contemporáneos/ Pontificia Universidad Javeriana/Instituto Pensar, 2007.

; MENDIETA, Eduardo (coords.). Teorías sin disciplina: latinoamericanismo, poscolonialidad y globalización en debate. México: Miguel Ángel Porrúa, 1998.

CESÁIRE, Aimé. Discourse on Colonialism. 1950. Disponível em: https://libcom.org/files/zz_aime_cesaire_robin_d.g._kelley_discourse_on_colbook4me.org_.pdf. Consulta em 05 mai. 2020.

CHAKRABARTY, Dipesh. Provincializing Europe: Postcolonial Thought and Historical Difference. Princeton University Press, 2000.

CEPAL. Os Povos Indígenas na América Latina: Avanços na Última Década e Desafios Pendentes para a Garantia dos seus Direitos. 2015. Disponível em: https://repositorio.cepal.org/bitstream/handle/11362/37773/1/S1420764_pt.pdf. Consulta em 05 mai. 2019.

ELECTORAL GEOGRAPHY. Bolívia: Presidential Elections. 2002, 2005, 2006, 2008, 2009A, 2009B, 2014, 2016. Disponível em: https://www.electoralgeography.com . Consulta em 05 mai 2019. ESCOBAR, A. El postdesarrollo como concepto y práctica social. En: Mato (Org.). Políticas de economía, medio ambiente y sociedad en tiempos de globalización. Caracas: Universidad Central de Venezuela, 2005, pp.17-31.

ESTERMANN, Josef. Filosofia Andina: Sabiduria Indígena para un Mundo Nuevo. La Paz: ISEAT, 2006.

FANON, Franz. Os condenados da terra. Juiz de Fora: Editora UFJF, 2010 [1961].

Black Skin, White Masks . 1986 [1956] Disponível em:

https://monoskop.org/images/a/a5/Fanon_Frantz_Black_Skin_White_Masks_1986.pdf. Consulta em 05 mai. 2020. 
GROSFOGUEL, Ramón. Para descolonizar os estudos de economia política e os estudos póscoloniais: transmodernidade, pensamento de fronteira e colonialidade global. Revista Crítica de Ciências Sociais, n.80, p.115-147, 2008.

- Descolonizando los universalismos occidentales: el pluri-versalismo transmoderno decolonial desde Aimé Césaire hasta los zapatistas. In: CASTRO-GÓMEZ, Santiago \& GROSFOGUEL, Ramon (coords.) El giro decolonial: reflexiones para uma diversidad epistêmica más allá del capitalismo global. Bogotá: Siglo del Hombre Editores, Universidad Central, Instituto de Estudios Sociales Contemporáneos, Pontificia Universidad Javeriana, Instituto Pensar, 2007.

Para descolonizar os estudos de economia política e os estudos póscoloniais: transmodernidade, pensamento de fronteira e colonialidade global. Revista Crítica de Ciências Sociais, n. 80, 2008, p. 115-147.

GUDYNAS, E. Transições ao pós-extrativismo. Sentidos, opções e âmbitos. In: Dilger, Gerhard; Lang; Miriam; Pereira, Jorge (Org.). Descolonizar o imaginário. Debates sobre pós-extrativismo e alternativas ao desenvolvimento. São Paulo: Elefante Editora, 2017.

. Extractivismos persistentes y el progresismo sudamericano. In: Daza, M.; Hoetmer, R. Y Vargas, V.: Crisis y movimientos sociales en Nuestra América: cuerpos, territorios e imaginarios en disputa. Lima, Programa Democracia y Transformación Global, 2012, p. 397-408 GUHA, Ranajit; SPIVAK, Gayatri Chakravorty. Selected Subaltern Studies. New York. Oxford University Press, 1988.

HALL, Stuart. Estudos culturais: dois paradigmas. In: Da Diáspora: identidades e mediações culturais. Belo Horizonte: UFMG, 2011. p.123-149

LANDER, Edgardo (org.). A colonialidade do saber: eurocentrismo e ciências sociais, perspectivas latino-americanas. Buenos Aires: Clacso, 2008.

LINERA, Álvaro García. A Potência Plebeia: Ação Coletiva e Identidades Indígenas, Operárias e Populares na Bolívia. São Paulo: Boitempo, 2010.

Las Tensiones Creativas de la Revolucion: La Quinta Fase del Proceso de Cambio. La Paz: Vicepresidencia, 2010a.

El Socialismo Comunitario: Un Aporte de Bolívia al Mundo. Revista Analisis: Entrevista con Álvaro García Linera. La Paz: Vicepresidencia, 2010 b.

MARIATEGUI, José Carlos. Sete Ensaios de Interpretação da Realidade Peruana. São Paulo: Expressão Popular/Clacso, 2008. 
. Por um Socialismo IndoAmericano. Rio de Janeiro: Editora UFRJ, 2005.

MALDONADO-TORRES, Nelson. La descolonización y el giro des-colonial. Tábula Rasa, v.2, n.9, p. 61-72, 2008.

Sobre la colonialidad del ser: contribuciones al desarrollo de un concepto. In: CASTRO-GÓMEZ, Santiago \& GROSFOGUEL, Ramon (coords.). El giro decolonial: reflexiones para uma diversidad epistêmica más allá del capitalismo global. Bogotá: Siglo del Hombre Editores; Universidad Central, Instituto de Estudios Sociales Contemporáneos, Pontificia Universidad Javeriana, Instituto Pensar, 2007.

MEMMI, Albert. O retrato do colonizado precedido pelo retrato do colonizador. Rio de Janeiro: Paz e Terra, 1967 [1965].

MIGNOLO, Walter. Pensamento decolonial, desprendimiento y apertura. In.: MIGNOLO, Walter (org.). Habitar la frontera: sentir y pensar la descolanialidad. Barcelona: CIDOB, 2015. Disponível em: http://www.cidob.org/content/download/64794/1995059/version/1/file/219-

324\%20HABITAR\%20LA\%20FRONTERA\%203\%20(3G)8.pdf. Acessado em: 05 mai. 2020.

. Desobediencia epistémica: retórica de la modernidad, lógica de la colonialidad y gramática de la descolonialidad. Argentina: Ediciones del signo, 2010.

MORALES AYMA, Evo. Palabras del Presidente Electo [Tiahuanacu, 21/01/2006]. Los Discursos de Evo. 2006A. Disponível em: https://www.pagina12.com.ar/diario/especiales/18-62330-2006-0130.html - consulta em 25/01/2019. Consulta em 05 mai. 2020.

.. Informe Anual de Gestion del Presidente a la Asamblea 2016 [22 de enero de 2017]. La Paz: Estado Plurinacional de Bolívia, 2017.

NCPE. Constitucion Política del Estado. Edicion Oficial. La Paz, 2009.

OJEDA, Igor. Povos Indígenas se Unem por Estados Plurinacionais. Revista Eletrônica ALAI, América Latina en Movimiento. 2008. Disponível em: http://alainet.org/active/21711\&lang=es. Consulta em 10 mar. 2014.

ORTEGA, Daniel. Bolívia: Lições de um golpe de Estado (parte 1). Disponível em: https://revistaopera.com.br/2019/11/26/bolivia-licoes-de-um-golpe-de-estado-parte-1/ . Consulta em 26 dez. 2019.

OPERA MUNDI [REDAÇÃO]. Pivo de um escândalo de corrupção: Ex Namorada de Evo Morales é Presa na Bolivia. 26/02/2016. Disponível em: http://operamundi.uol.com.br/conteudo/noticias/43343/pivo+de+um+escandalo+de+corrupcao+exnamorada+de+evo+morales+e+presa+na+bolivia.shtml. Consulta em: 20 nov. 2017. 
PORTO-GONÇALVES, Carlos Walter. Latifundios genéticos y r-existencia indígena. Revista Chiapas, nº 14, UNAM, D.F., México, p. 7-30, 2002.

PRIMER MANIFESTO DE TIAHUANACO. 1973. Disponível em: http://movimientoindianistakatarista.blogspot.com.br/2014/06/manifiesto-de-tiahuanaco1973 29.html . Consulta em 19 mai. 2015.

QUIJANO, Anibal. Colonialidad y modernidad-racionalidad. 2005. Disponível em: <http://pt.scribd.com/doc/36091067/Anibal-Quijano-Colonialidade-e-ModernidadeRacionalidade>. Acessado em 05/05/2020.

RIVERA CUSICANQUI, Silvia Rivera. Oprimidos pero no Vencidos: Luchas del Campesinato Aymara y Qhechwa (1900-1980). La Paz: La Mirada Salvaje, 2010.

Aires: Tinta Limón, 2015. Sociologia de la Imagen: Ensayos. Ciudad Autonoma de Buenos Etnicidad Estratégica, Nación y Colonialismo en América Latina. Conferência Inaugural do IV Congreso Internacional sobre Dinámicas de Inclución y Exclusión en América Latina. Universidad de Colonia: México, 2013. Arquivo em Vídeo Disponível em: http://teresanalvarez.com.ar/etnicidad-estrategica-nacion-y-colonialismo/\#axzz2rt6zrKL4. Consulta em 30 jan. 2013.

SAID. Edward W. Orientalismo: o Oriente como invenego do Ocio dente / Edward W. Said ; traducáo Tomás Rosa. Bueno. - Sao Paulo : Companhia das Letras, 1990 [1978].

SANTOS, Boaventura de Sousa Santos e CUSICANQUI, Silvia Rivera. Conversatios of the World IV/Conversas del Mundo IV: Valle de las Animas (La Paz/Bolívia). 2013. Disponível em: http://alice.ces.uc.pt/en/index.php/santos-work/conversation-of-the-world-iv-boaventura-de-sousasantos-and-silvia-rivera-cusicanqui-2/?lang=pt . Consulta em 05 mai. 2020.

Cortez, 2010. ; MENESES, Maria Paula (orgs.). Epistemologias do Sul. São Paulo:

SHAVELZON, Salvador. A Assembleia Constituinte na Bolivia: Etnografia do Nascimento de um Estado Plurinacional. Tese de Doutorado em História. Rio de Janeiro: UFRJ, 2010.

SPIVAK, Gayatri C. Can the subaltern speak? In: NELSON, Cary; GROSSBERG, Lawrence (eds.). Marxism and the interpretation of culture. Chicago: Chicago Press, 1988. p. 271-313. 
SVAMPA, M. Extrativismo neo-desenvolvimentista e movimentos sociais. In:Dilger, Gerhard; Lang; Miriam; Pereira, Jorge (Org.). Descolonizar o imaginário. Debates sobre pós-extrativismo e alternativas ao desenvolvimento. São Paulo: Elefante Editora, 2017.

VIEZZER, Moema. "Se Me Deixam Falar...”: Testemunho de Domitila Barrios de Chungara, uma mulher da Bolívia - 25 anos depois. São Paulo: Global Editora, 2003.

ZAVALETA MERCADO, René Consideraciones generales sobre la historia de Bolivia. In: Pablo González Casanovas (comp.), América Latina: historia de medio siglo. México, Siglo xxi, 1977. 